\title{
Å bære frukter
}

«Det er første gang man har forsøkt at kombinere fødehjem og mødrehjem», står det om denne bygården like ved Sarpsborg sykehus (Tidsskr Nor Lægeforen 1917; 37: 764-6). Midlene var samlet inn fra bedrifter, kommuner og private, og driften skulle finansieres fra ulike offentlige ordninger og kvinnene selv. Veldedigheten kom ikke uten forventning om motytelse.

\section{Hygieniske meddelelser og social medicin.}

\author{
Mødrehjem for Smaalenene. \\ Av P.K. Bretteville-Jensen, Sarpsborg.
}

(...) Hjemmet blev straks av arbeidskomiteen besluttet forbundet med et fødehjem, hvor enhver kvinde, som venter sin nedkomst, kan indlægges mot vanlig sykehusbetaling. Denne avdeling er derfor tænkt at skulle bære sig økonomisk, mens mødrehjemmet ifølge hele sit anlæg maa gaa med et visst underskud. Men man antok, at det vilde være en praktisk kombination $i$ en mindre by, hvor man jo ikke har nogen «fødselsstiftelse» forresten, idet det vilde være naturlig og økonomisk at ha samme bestyrerinde, kjøkken, bad og fødeværelse osv. baade for de ugifte mødre, for hvem hjemmet var beregnet, og for en slik liten enkel «kvindeklinik», hvor mangen en træt arbeiderhustru og andre, som har det litt trangt hjemme, kunde faa den nødvendige ro under fødsel og barselseng.

Disse siste skal da efter planen bare opholde sig de vanlige 14 dage paa fødehjemmet, mens det er planen, at de ugifte mødre skal kunne opholde sig paa hjemmet i mange maaneder og for en billig penge - ca. $1 \mathrm{kr}$. pr. dag. Til gjengjæld er det let, naar pikerne selv er kommet til kræfter, at la dem utføre arbeide ogsaa ved fødehjemmet, hvad der yderligere tjener til at utdanne dem til dygtige hjælpersker i barselpleie og barnestel. Herved - ved efterhvert at skape en liten stab av saadanne, som kan bli til nytte i samfundet - haaber man at faa dobbelt igjen for at ha hjulpet disse ofte ulykkelige ensligstillede kvinder, som i den tid de er paa hjemmet først og fremst har lært at stelle sit eget barn - amme det - holde av det, og saa helst kan faa ta det med til det sted, hvor de dernæst søkes sikret en god og betrygget fremtid.

Mødrehjemmet har to mindre værelser for betyrerinden, kjøkken, en fælles spisestue, arbeidsrum og to større værelser, hvor det er plass til 6 à 8 mødre med deres barn.

Ovenpaa er fødeværelset, bad, pikeværelse og 3 værelser for tilsammen 6 à 8 barselkoner.

- I den tid hjemmet har virket har mødrehjemmet til stadighet været fuldt, mens søkningen til fødehjemmet hittil ikke paa langt nær været saa stor, som man hadde ventet. Vistnok vil jo fødehjemmet bare faa sit naturlige belæg fra Sarpsborg by og de nærmeste bygder, mens mødrehjemmet faar sine fra det hele amt - men tallet paa dem, som lægger sig ind paa fødehjemmet er dog endu uforholdsmæssig lavt. Sikkert beror dette for en stor del derpaa, at mødrene saa nødig helt tør forlate sine hjem for selv at søke pleie, fordi det er saa vanskelig at faa paalidelig hushjælp under deres fravær.

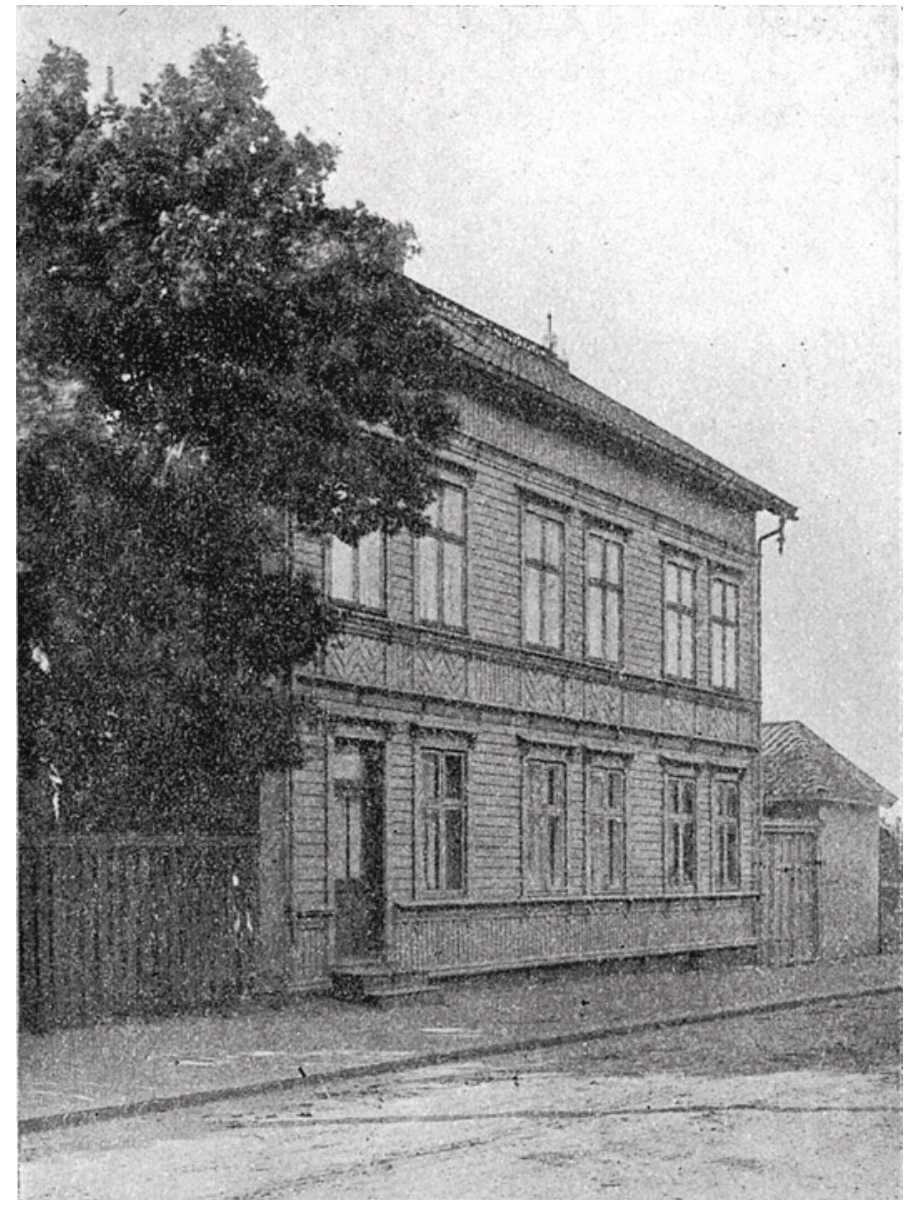

